\title{
The importance of the essayist on social issues
}

\author{
by Andrew Brink with Richard A. Rempel
}

\section{INTRODUCTION}

My social and political essays have had as their object the diminution of cruelty and ignorance in human affairs. ${ }^{1}$

EDITING A WRITER's work is an act of criticism. It represents a judgment about the intellectual and literary worth of that work. By editing the non-technical writings of Bertrand Russell, we are saying more than that they are a group of important modern essays needing to be seen together. We are claiming that they are the single most important set of essays by a liberal thinker within the past century. Russell's essays have entered and shaped the modern mind. As a thinker, his power is generally acknowledged; as a prose stylist he has few peers; but as a master of the prose of thought he is unsurpassed. Whether or not we agree with his opinions and arguments, it cannot be doubted that they are brilliantly conveyed-most brilliantly in the essays. Russell combines penetrating thought on the most timely topics with a prose style of clarity and precision. Yet Russell's essays have never been presented in a comprehensive and reliable edition, despite the fact that he was writing publishable essays as early as the 1890 s.

Russell was always a writer with a message, a writer wishing to persuade us to thought and action out of the deepest concern for human advancement. He received the Nobel Prize for literature, awarded for his "versatile and important writings in which he had shown himself an apostle of humanity and freedom of thought". The

' Bertrand Russell to Karel Berka, 27 Sept. 1966 (Russell Archives). 
humanitarianism grew out of a long struggle to find himself in the intellectual landscape of late Victorian and Edwardian England. It led him to a liberal humanism tinged with sadness for the tragedy of human life, a feature which prevents Russell's driving optimism in the triumph of reason from appearing facile. Freedom of thought and an independent spirit were the necessary conditions for a man to make any contribution, given the modern world's confusions. In one of his briefest but most telling essays, "What I Have Lived For", the prologue to Volume I of his Autobiography, Russell writes that "three passions, simple but overwhelmingly strong, have governed my life: the longing for love, the search for knowledge, and unbearable pity for the suffering of mankind. These passions, like great winds, have blown me hither and thither, in a wayward course, over a deep ocean of anguish, reaching to the very verge of despair"' ${ }^{2}$ But Russell is no purveyor of despair. His anguish is transformed into positive social criticism and the prophecy that by recognizing true human interest we can build a better world. This prophecy is most notably made through the essays, which almost always touch at least one of his three passions. The essays define and make specific the wish to understand human love better, to acquire exact knowledge and to prevent or alleviate human suffering. Because they are so often written at this level of concern, Russell's essays are of permanent importance in the moral tradition of the West.

Russell wrote many books of social and intellectual importance, yet it is certain that the Nobel literary award recognized his preeminence as an essayist. Russell himself collected ten volumes of essays (a small proportion of the 70 volumes of his published work), but most of his books themselves can be seen as collections of essays. Whether he is writing on social theory as in Freedom and Organization, 1814-1914 (1934) or philosophy as in A History of Western Philosophy (1945), the essay form prevails. It is Russell's natural unit of thought, which he adjusted to many and various intellectual tasks throughout his lifetime. As his natural unit of thought, the essay underwent refinements in his hands that only a full survey of its use can show. We do not know the extent of his development of the essay because literary historians have not yet seen the whole picture clearly before them. Indeed, except for DasGupta, ${ }^{3}$ Brink, ${ }^{4}$ and Leith-

${ }^{2}$ (London: George Allen \& Unwin, 1967), p. 13.

${ }^{3}$ R. K. DasGupta, "Russell as a Man of Letters", Russell, no. 9 (1973), 3-14.

4Andrew Brink, "Russell to Lady Ottoline: The Letters of Transformation", Russell, nos. 21-22 (1976), 3-15. auser, ${ }^{5}$ and as W.W. Robson ${ }^{6}$ points out, almost nothing has been written on Russell by literary historians and critics. We know that he adapted the essay to many purposes, from the most self-consciously literary to the most rigorously informative and exhortatory, but the exact development needs study. Russell followed the central English essay tradition more closely than did any contemporary. The mainly uncollected shorter writings, the essays, form Russell's claim to lasting literary importance. How they have shaped thought and opinion in the modern world can only be judged if they are seen together. It is McMaster's responsibility as curator of this material to see that the task of making it available to scholars is not indefinitely postponed. A chronological edition would best reveal the diversity of thought and style among these 2,500 essays and other shorter public writings, showing the sweep of his intellect over the entire era of social and political and intellectual upheaval from the late 1880 s to 1970.

\section{RUSSELL AND THE PRE-VICTORIAN TRADITION}

Russell carries forward the strongest elements of the English essay tradition: wit and argumentation tempered by a harmlessly roguish personal presence. He loved to argue; he made an art of arguing well at the educated layman's level (while he made a science of arguing in the technical philosophical papers). In the essays he thought of as "popular" for their unpopular opinions, Russell argues wittily and divertingly but always with the serious intention of a reformer. An example of his wit and asperity is found in a serious piece of 1918, "The German Peace Offer". The first sentence brought him into trouble with the authorities and has been quoted often, but its full context is necessary for it to be appreciated:

The American Garrison which will by that time be occupying England and France, whether or not they will prove efficient against the Germans, will no doubt be capable of intimidating strikers, an occupation to which the American Army is accustomed when at home. I do not say that these thoughts are in the mind of the Government. All the evidence tends to show that there are no thoughts whatever in their mind, and that they live from hand to mouth consoling themselves with ignorance and

"Gladys Garner Leithauser, "Principles and Perplexities: Studies of Dualism in Selected Essays and Fiction of Bertrand Russell" (PH.D. thesis, Wayne State University, 1977). ${ }^{6}$ W. W. Robson, review of Clark's Life of Bertrand Russell, Partisan Review, 45 (1978),
$636-41$. 
16 Russell, nos. 33-4 (Spring-Summer 1979)

sentimental twaddle. I say only that if they were capable of thought, it would be along such lines as I have suggested that they would have to attempt to justify a refusal to make Peace on the basis of the German offer, if indeed they do decide to refuse. ${ }^{7}$

Russell's most evidently literary productions are not necessarily his best writings. As an imaginative short-story writer Russell is less effective than as an argumentative essayist. (Indeed many of the short stories turn out to be imaginative essays.) At his best Russell the essayist argues the truths he sees to the point of absurdity, then leaves the reader to ask himself: "What's wrong with that argument; is there a better one?" This tactic has an important function in a democratic society.

Russell is a master essayist partly by reason of awareness of the great tradition in which he worked, a tradition descending from the Renaissance. Over more than 300 years the essay has become a civilized and highly flexible unit of exposition and argumentation. The essay is a brief, concise literary form which holds the reader's attention for a short duration on a specific, limited subject. It fits admirably the temper of Russell's mind, which Santayana likened to "an intensely concentrated searchlight". 8 The subject of the essay is often, but not always, of immediate and broadly recognized social importance. It may be a subject of reflective or personal interest attaining as deep a resonance as in any other prose form. Precisely to define the essay is impossible, so many are its varieties. Russell covered most of them, in both the formal and informal or familiar modes. The essay flourishes most strongly in periods of rapid social change, in which it is not only the more intellectually aware public that is left bewildered and in need of special guidance. Two such periods are the Renaissance (the late sixteenth and early seventeenth centuries in England) and the modern period, which we may extend back to late Victorian times, when the dynamic of industrialism and urbanization became disturbingly apparent. Similarly the Renaissance saw traditional religious and social forms challenged. The Renaissance essay is an outgrowth of the shift from a relatively impersonal medievalism to a heightened self-consciousness.

Russell is detectably a Baconian. The late sixteenth-century essays of Sir Francis Bacon are more concerned with the politics of self-

7 "'The German Peace Offer", The Tribunal, no. 90 (3 Jan. 1918), 1.

${ }^{8}$ George Santayana, "Bertrand Russell's Searchlight" (review of Religion and Science), American Mercury, 37 (1936), 377-9. Reprinted in his The Birth of Reason and Other Essays, ed. Daniel Cory (New York: Columbia University Press, 1968). advancement, with advice on how to succeed in the precincts of power, than Russell would wish to follow. He, by contrast, always mistrusted concentrations of power. Bacon's scepticism toward received opinion and his plan to reform and to purify thinking habits are wholly congenial to Russell, as is the aphoristic pungency of his style that exemplifies clear thinking. Bacon's range of subjects, which cover all areas of life-from love, marriage and children to travel and politics-is Russell's range, too. Bacon urged critical intelligence and disbelief in what cannot be certainly demonstrated; like Russell, he wrote technical books and more popular essays to complement them. He was, in short, a rationalist who used the essay to design adaptively for a world changed by scientific discovery and by the politics of Machiavellian power-seeking. In short, Bacon wrote to promote a value system for the emergent social order. He was a "new man" of the Renaissance, as was Russell of the postVictorian modern age. For both, the essay has utmost utility, though Russell is a much greater humanitarian than Bacon.

Another essayist, Michel de Montaigne, whose Essays were made famous in England when published in John Florio's translation (1603), may have influenced Russell. Montaigne is the Renaissance's most astute psychological observer, who devised the essay to convey what could be known of human behaviour. He writes: "So from my friends' outward manifestations I discover their inward inclinations." Russell does not make such claims to insight, but many of his biographical and autobiographical essays are astute readings of character. He is unafraid of being controversial and outspoken about the faults he sees in people. Of D. H. Lawrence's prophetic ideas, for example, he says: "They were the ideas of a sensitive would-be despot who got angry with the world because it would not instantly obey." But Russell, who knew a surprising number of the formative people in his time, could also be warmly appreciative, as in the essays on Joseph Conrad and Alfred North Whitehead gathered in Portraits from Memory (1956). Montaigne represented the new Renaissance awareness of human complexity, to its extreme of spiritual alienation. Russell writes in the era of scientific psychology, uncertain whether to credit J.B. Watson's behaviourism or the Freudian theory to which he was also sympathetic. In evaluating character he settles for the no less exacting values with which he was brought up-truthfulness and consistency with principle. Among modern writers Russell is closest to being a "Renaissance Man" for his comprehensive range of enquiry and remarkable ability to synthesize in prose even the most difficult thought; it is therefore not misleading to draw these parallels when speaking of Russell as an essayist. 


\section{RUSSELL AND THE VICTORIAN TRADITION}

The other period of stirring social change which stimulated the essay was the Victorian. In certain ways Russell was a Victorian-he was 28 at the turn of the new century. But he tried to accommodate to post-Victorian conditions the social, ethical and religious value systems which had impressed him in his youth. The strict social and moral codes Russell learned under the tutelage of his paternal grandmother seemed to him out of phase with the emergent world of science and mass politics that "progress" had brought. He wrote as a libertarian, questioning as a Baconian sceptic many of the rules of social obligation to which Victorians agreed but moderns could not. Russell was a harsh critic of the Christian church, just as he was unwilling to accept most of the upper-class conventions in which he was brought up. Yet he was much more than an iconoclast; unlike his friend Lytton Strachey and Bloomsbury as a whole, Russell has much to say in commendation of the Victorians, especially the reforming liberals. ${ }^{9}$ For instance, the essay on his grandfather, the Prime Minister Lord John Russell, commends him for "carrying the Reform Bill of 1832, which started Britain on the course that led to complete democracy". This essay ends with a passage summing up the sort of historical accommodation to the modern world that the younger Russell hoped to achieve:

The men of my grandfather's age falsely prophesied prosperity and were believed. If he could come back into our present world he would be far more bewildered than his grandfather would have been by the nineteenth century. For those who have grown up in the atmosphere of a strong tradition, adaptation to the world of the present is difficult. ${ }^{10}$

Russell was familiar with the whimsical essay from Charles Lamb's Essays of Elia (1823), the periodical essay from the eighteenth-century collections of Addison and Steele, and the review essay from the great nineteenth-century review journals, The Edinburgh, The Quarterly and The Westminster. These had such eminent contributors as T.B. Macaulay, Matthew Arnold, Thomas Carlyle and George Eliot. Russell's father, Viscount Amberley, was a contributor of critical essays to the Westminster Review. These critical,

y "Toleration", The Listener, 39 (1948), 695-7. Reprinted in Ideas and Beliefs of the Victorians: An Historic Revaluation of the Victorian Age (London: Sylvan Press, 1949).

${ }^{10}$ Portraits from Memory and Other Essays (London: George Allen \& Unwin, 1956), pp. 112-13. formal essays of earnest concern about a range of social and literary issues gave Russell his literary direction. The essay was the most important pre-electronic means of reaching the most influential portion of the thinking public. Russell read widely, from the philosophers Locke and Hume, to the aesthete Pater, and the art critic Ruskin. Of American essayists, Russell admired the critic James Russell Lowell and the transcendentalist Ralph Waldo Emerson. Russell tells us that he looked as far back as Milton when considering what style he might emulate. Eventually he found one of precision and beauty that is completely his own. He had worked at style from an early age: "From the age of about 16 onwards, I formed the habit, in thought, of turning a sentence over and over in my mind, until I had a combination of brevity, clarity and rhythm". ${ }^{11}$ It was a style in which he could redirect, for his own times, the nineteenth-century debates on great issues, believing that democracy depends on informed intelligence.

Russell could not have ignored Matthew Arnold's pleas for authoritative culture over the anarchistic "God-given right of every Englishman to do as he likes". Arnold's Culture and Anarchy (1869) was directed against Mill's On Liberty, and was intended to counteract its attack on "the despotism of custom" and its assertion that "genius can only breathe freely in an atmosphere of freedom". Through "culture" Arnold hoped for a disciplined community in which the individual subordinated his wants to the legitimate claims of the collectivity. Mill's liberalism pointed the other way-towards permitting as much private satisfaction as did not harm the community. Mill's advice, not Arnold's, has been taken in the Englishspeaking world, with Russell the essayist in its vanguard. Yet the Russell who battled for new freedoms saw the old question of the need for a balance between society and the individual. He writes: "Great ages and great individuals have arisen from the breakdown of a rigid system: the rigid system has given the necessary discipline and coherence, while its breakdown had released the necessary energy"'. ${ }^{12}$

Similarly from T.H. Huxley, Darwin's essay-writing defender, Russell must have learned some respect for the evolutionary argument for man's origin and development. Prophetic Biology had a brilliant apologist in Huxley: "We are in the midst of a gigantic

\footnotetext{
" Russell to Josephine K. Piercy, 6 Aug. 1925. Quoted in part in Piercy's Modem Writers at Work (New York: Macmillan, 1930); in full in K. Blackwell, "How Russell Wrote", Russell, no. $8(1972), 13-15$.

12 Why I am Not a Christian, ed. Paul Edwards (London: George Allen \& Unwin, 1957), p. 89.
} 
movement, greater than that which preceded and produced the Reformation." Russell knew that after Darwin traditional social authority could no longer hold sway over the drive to enquire into nature's deepest processes. He also knew that increasingly man's evolutionary direction has fallen to his own control. Either we make wise choices based on foresight, or our high place in nature will be lost. In "Men versus Insects" he writes:

If human beings, in their rage against each other, invoke the aid of insects and micro-organisms, as they certainly will do if there is another big war, it is by no means unlikely that the insects will remain the sole ultimate victors. Perhaps, from a cosmic point of view, this is not to be regretted; but as a human being I cannot help heaving a sigh over my own species. ${ }^{13}$

\section{THE ESSAYIST ON HISTORY AND THE SOCIAL SCIENCES}

Russell grew up in an atmosphere of strong literary and family tradition. Part of his aristocratic inheritance he would never jettison, and this legacy is unmistakable even in his most critical essays. Russell's family was so interwoven with the aristocracy that shaped the Whig side of British history that he could not ignore its teaching. Fortunately for his temperament, his family tradition was liberal and reforming, the best outgrowth of a seventeenth-century Puritan legacy. Nevertheless, Russell had to think his way through to first principles in all departments of life, so challenged did he feel by the disjunction of modernity from Victorianism. Yet several nineteenth-century essayists back him in his quest for certainty about the values he wished to affirm and others he wished to deny. First, Russell's love of history, his immersion in it, was served by Macaulay, the Whig historian who exhorted that to judge the present one must first have understood the past. Russell, of course, was aware of British parliamentary history by "breathing it" in his grandfather's library at Pembroke Lodge, where he grew up. He was just as aware of the history of history writing in England. When Russell writes in "History as an Art" of the "long procession from Clarendon's History of the Rebellion to Macaulay", 14 he means that he has read and considered the changing styles and perspectives in the writing of history.

\footnotetext{
${ }^{13}$ In Praise of Idleness and Other Essays (London: George Allen \& Unwin, 1935), p. 201.
${ }^{4}$ Portraits from Memory, pp. 189-90.
}

Russell wrote about historians and history with knowledge and insight. He understood the limitations of the Whig history by which he had been reared, and he grasped the potential of what is today the genre of social history initiated by E.P. Thompson. Yet he continually stressed, in ways that cause many contemporary historians to wince, the role of the individual in history as opposed to explanations that rely on impersonal forces, whether climate or classes. This belief of Russell's was not an old-fashioned clinging to earlier historiographical approaches; it resulted from his conviction that ideas have consequences and that, therefore, seminal thinkers have to be understood by historians and layman alike. Apart from The Amberley Papers (which he edited with his third wife) and his more topical books, Russell was not concerned with historical research through the detailed examination of primary sources. Consequently it is true that, like many late Victorian and early twentieth-century British historians, he too frequently sacrificed accuracy or ignored sources. In Russell's case such historiographical weaknesses occurred because he was most concerned with conveying a general idea or battling what he considered to be a pernicious institution or concept. But in doing so he attacked vehemently and often shrewdly philosophies of history that claim to predict the future. Such philosophies he considered unscientific. He also quarrelled with the exclusively literary conception of history advanced by his friend G. M. Trevelyan, and called for the employment of scientific methodology whenever possible.

He was concerned to cultivate for a mass readership a sense of the value and pleasure to be obtained from reading history. He desired readers to compare whole civilizations as well as to assess world leaders, past and present. Because the range of his knowledge was so great and his mind so penetrating, his historical writings traverse an enormous span of both subjects and eras. He was aware that he would be faulted for this attitude to historiography. Hence he was gratified when he had occasion to write to Hugh Trevor-Roper that: "In general specialists do not like the intervention of others in their field but your letter made me suppose that you do not wholly despise my occasional incursions into history". ${ }^{15}$ Since Russell viewed his historical works essentially in a controversialist, stimulative fashion, he ought not to be judged by the criteria of modern academic historians. Russell admired many academic historians and he hoped that his essays on history would lead laymen to read professional historians.

Russell was a participant in some of the history he wrote about-

${ }^{15}$ Russell to Hugh Trevor-Roper, 7 Jan. 1964 (Russell Archives). 
few in Britain, for example, have contributed as much to pacifist theory and practice-and hence many essays, editorials and letters compose the material that should be available for the work of academic historians and political scientists. His essays on history, political behaviour and biography have the qualities of clarity and range, and they accord him an honourable place in English historiography. If Russell rejected any encompassing theory of historical causation, so also do many professional historians. Like Winston Churchill in his Great Contemporaries, Russell could often portray with freshness and originality leading thinkers and politicians of his own and earlier times. In the end, Russell's writings on history, social and political theory will be judged largely for their impact on a mass audience and for what they tell us about his own values.

History and its interpreters were a force throughout Russell's intellectual life. But as a spiritual forbearer in the essay, John Stuart Mill is more important than any historian. Mill was Russell's "godfather" (in the somewhat altered sense that his parents and Mill used the term). Mill wrote on subjects that became central to Russell's philosophical work and to his essays: logic, scientific method, political economy, religion, liberty and women's suffrage. In one essay on Mill, Russell writes: "With Mill's values, I for my part find myself in complete agreement". ${ }^{16}$ Mill was his main liberal exemplar, a powerful essayist and social prophet, whose thoughts on the limits of liberty Russell carried forward with the developments and qualifications necessary to a very different age ${ }^{17}$ Much of this essay on Mill examines the applicability of his principles of liberty to social conditions that Mill could not have predicted in 1859, the date of $O n$ Liberty. Russell reassesses the traditional English intellectual concern with individual freedom, descending to Mill from John Milton in the seventeenth century; if there is a line of descent it is this, Milton, Mill, Russell: giving purpose to a number of his most important essays distributed over a long period of time. Such essays as "Freedom versus Authority in Education" (1924) and "Freedom in Society" (1926) are the bulwarks of Russell's thinking about society.

Russell's political thought, which is already the subject of some 48 scholarly books and articles, ${ }^{18}$ will demand further analysis once his essays are edited developmentally. An early unpublished journal and

\footnotetext{
16 Portraits from Memory, p. 124.

17 See Richard Wollheim, "Bertrand Russell and the Liberal Tradition", in G. Nakhnikian, ed., Bertrand Russell's Philosophy (London: Duckworth, 1974).
}

18 See "A Secondary Political Bibliography of Bertrand Russell" in this issue of Russell. some adolescent and Cambridge essays will reveal Russell attempting from the late 1880 s to face the dilemmas he perceived in the inadequacies of Gladstonian Liberalism. Russell's evolution towards and contributions to the New Liberalism have been almost entirely overlooked despite the growing literature on this ideology by, in particular, Freeden ${ }^{19}$ and Clarke. ${ }^{20}$ As well, his political views on guild socialism, syndicalism, and political extremes such as fascism, will only be understood clearly if all of his political writings are presented systematically in chronological order. (For example, as late as 1968, he still endorsed workers' control in industry as the only means of preventing the tyranny of state socialism. ${ }^{21}$ ) Such a systematic edition of his political thought and activity would refine our understanding of Russell's liberalism, his internationalism and his conception of liberty. It is well to note, what has generally gone unnoticed, ${ }^{22}$ that a reconciliation of socialism and liberalism, a "socialism with a human face" such as is associated with the Dubcek experiment in Czechoslovakia, was advocated by Russell as early as the 1920s. Thus while Russell's historical writings are more diverse and idiosyncratic, his essays on political theory, which he valued very highly, stand in the classical English empirical tradition.

Often Russell's political and economic writings-essays, editorials and reviews-also provide invaluable accounts of the many campaigns and issues in which he was involved. His free trade essays, reflecting a sophisticated grasp of Marshallian economic theory, show his passionate and significant participation in the tariff reform agitation that frequently convulsed Edwardian politics. ${ }^{23}$ For the rest of his life, Russell continued to write informed (if popular) essays on economic questions such as unemployment and the evils of oligopoly and monopoly (including Middle Eastern oil ${ }^{24}$ ). He campaigned for policies of increased government spending to encourage employment in ways classically formulated by his lifelong friend, John Maynard Keynes. Above all, he was concerned to reconcile

19 Michael Freedan, The New Liberalism: An Ideology of Social Reform (Oxford: Clarendon Press, 1977).

20 Peter F. Clarke, Liberals and Social Democrats (Cambridge, Eng.: Cambridge University Press, 1978)

${ }^{21}$ Russell to Hugh Scanlon, 8 May 1968 (Russell Archives).

${ }^{22}$ See Louis Greenspan, The Incompatible Prophecies: An Essay on Science and Liberty in the Political Writings of Bertrand Russell (Oakville, Ont.: Mosaic Press/Valley Editions, 1978). [Reviewed in this issue of Russell.]

${ }^{23}$ Richard A. Rempel, "From Imperialism to Free Trade: Couturat, Halevvy and Russell's First Crusade", Fournal of the History of Ideas, 40 (1979), 67-87.

${ }^{24}$ B. Russell, "The Politics of Oil: The Threatened Combine of Combines", New Leader, 6 (11 Jan. 1924), 4-5. 
democracy and a planned economy. ${ }^{25}$ Similarly, his writings on women's suffrage and birth control must be seen in the context of his active advocacy of those causes. Russell's Tribunal editorials ${ }^{26}$ constitute perhaps the single most important source of pacifist ideas and tactics during the Great War. Since he was active in so many other campaigns, particularly of world-wide interest after 1945, his writings on the nuclear peril and disarmament, McCarthyism, Suez, and, certainly not least, Vietnam, form some of the crucial documentation through which these questions must now be studied to be understood. Of these campaigns none was more important than his leadership in creating a world climate of opinion that helped push Russia and America to the test-ban treaty of 1963. Russell's relationship to the rise of the New Left, which is also associated with these campaigns, has yet to be studied.

Russell's importance to what we know as the social sciences needs special emphasis. He is a forerunner of much that is studied not only in politics but in sociology, psychology and education. It is well known that before the new century's turn Russell began systematic study of the social trends that were leading to altered political systems. His first book, German Social Democracy (1896), considers political imbalances in a society undergoing democratization. Russell foresaw Germany's emergence into modern warmaking and dictatorship. It was, however, the revulsion caused by the Great War that put Russell in the forefront as an analyst of social issues that lead to war. Principles of Social Reconstruction (1916) is one of the most important sets of proposals for a warless world to come out of the holocaust that many said ended traditional European civilization. Russell looked for a new synthesis of values to support a just society: the book considers war, private property, education, marriage, the population question, religion and the churches. Prophetically it puts forward a plan for world government, which Russell never ceased to advocate. Principles of Social Reconstruction is an outline for later elaborations of these and related topics in such books as Freedom and Organization, 1814-1914, Power: A New Social Analysis (1938), New Hopes for a Changing World (1951) and Human Society in Ethics and Politics (1954). An inference from these studies is that our educational systems have to be rethought. Russell's realization that the renewal of society must rest on reformed education led to the establishment of Beacon Hill School in 1927. His two books and many essays on

${ }^{25}$ See his little-known essay, "Democracy and the Economic System", Lecture II in the series, "Problems of Democracy", c.1942 (MS, Russell Archives).

${ }^{26}$ See John G. Slater, "Bertrand Rusell and The Tribunal", Russell, no. 1 (1971), 6-7. education place him alongside the educational reformers John Dewey and A.S. Neill. The outcome of the Beacon Hill venture, which applied Russell's and his wife Dora's advanced thinking, is now a topic of extensive academic study and debate. ${ }^{27}$

Further, Russell can be placed in a network of early twentiethcentury writers who sought release from Victorian restrictions on sexuality. Victorian morality was brought under attack from several quarters, among them the emergent social sciences backed by dissident writers. Attacks were of varying strengths from writers on sexuality with whom Russell is known to have been familiar. From Walt Whitman's erotic verse effusions he moved to the more controlled recommendations of Edward Carpenter, whose Sex Love Russell called in a letter to Alys Pearsall Smith "the only good thing I ever read on the subject". ${ }^{28}$ Russell pursued the subject with some care. His library contains an obviously read copy of Havelock Ellis's Man and Woman (1926), and Russell wrote an approving review of his Psychology of Sex, commending Ellis for "the complete sanity of his outlook". ${ }^{29}$ As an advocate of birth control, Russell shared the concern of such well known campaigners as Marie Stopes and Margaret Sanger. ${ }^{30}$ His Marriage and Morals (1929) discusses not only contraception but the history and anthropology of marriage customs, the liberation of women, sexuality in all its aspects, prostitution, trial marriage, the family, divorce, population and eugenics. He wished to train rather than to thwart instinct, and banish a needless sense of sin, replacing it with a measured hedonism that takes into account the rights of children. In this book, and in The Conquest of Happiness (1930), Russell sought to liberate individuals from the excesses of Victorian repressiveness, trusting that a responsible, non-theistic, rational morality would be built. Marriage and Morals had a powerful impact, judging from its wide reviewing in the popular as well as the intellectual press. This book placed Russell together with G. B. Shaw and H. G. Wells as the main spokesmen for a "new morality", which has gained in social influence ever since. Deserving of brief mention

\footnotetext{
${ }^{27}$ See Howard Woodhouse, "On a Suggested Contradiction in Russell's Educational Philosophy", Russell, no. 15 (1974), 3-14, and "Repression in Bertrand Russell's On Education" (read to the Bertrand Russell Society at the December 1978 meeting of the American Philosophical Association); and David Harley, "Beacon Hill School", forthcoming in the issue of Russell.

${ }^{28}$ Russell to Alys Pearsall Smith, 4 Feb. 1894 (Barbara Halpern papers, Oxford; microfilm in Russell Archives).

29 "Havell Archives)

29 "Havelock Ellis on Sex", New Statesman and Nation, n.s. 5 (18 March 1933), 325-6.

${ }^{30}$ See Diane M. Kerss, "Russell, Stopes and Birth Control", Russell, nos. 25-28 (1977), 72-4.
} 
are Russell's environmental concerns ${ }^{31}$ and his general concerns for man's behaviour in large urban concentrations. ${ }^{32}$ Even geographers have found research in Russell worthwhile. ${ }^{33}$ Thus Russell deals with a wide range of topics studied in the social sciences, and when his writings come to be assessed a sizeable proportion, including many essays, will fall within the scope of psychology and sociology, whose histories may well record his part.

\section{THE MASTER ESSAYIST}

As the twentieth century grew politically more dangerous, a note of concern for the whole human race was increasingly sounded by Russell. Russell was among the first to see that emancipated individualism, unrestrained science, and industrialism defined a very different future for western man than many optimists had believed. He could see that the human spirit might shrivel under these influences. Russell bridged the gap between unrealistic optimism about human progress and the confusion and despair which pervade the modern world. He was neither unrealistic nor despairing in his public statements, but a voice pleading for the clear analysis of the problems of survival. Many of his finest essays come from the closing decades of his very long life when, if anything, his passion for mankind's welfare increased. His style was then just as consummate as ever but more sparing. In a few paragraphs he could trace a social current, or weigh the justice of a political system. Among his most important warnings are "Symptoms of Orwell's 1984", which detects features of Orwell's nightmare already come to pass, the worst being loss of liberty. To give historical perspective, Russell writes: "Only those who remember the world before 1914 can adequately realize how much has already been lost". ${ }^{34}$

In "Why I am not a Communist" Russell powerfully advances the anti-Marxism he had always argued-even before visiting postrevolutionary Russia in 1920 . He cannot accept Marxism because he finds it to be based on hatred and the ideology of dialectical materialism. From 1896,35 he contributed significantly to debates on the intellectual merits of Marxism and the practical merits of com-

${ }^{31}$ Mentioned first in Principles of Social Reconstruction.

32"If I Were Dictator of Housing-", Sunday Referee, 13 Aug. 1933, p. 6.

${ }^{33}$ Ronald Bordessa and Vykki J. Silzer, "Bertrand Russell's Response to Environment", Places, 1 (1974), 37-42.

34 Portraits from Memory, p. 203.
35 See Kirk Willis, "The Critical Reception of German Social Democracy", Russell, nos. 21-22 (1976), 35-45. munism: "I have always disagreed with Marx ... my objections to modern Communism go deeper than my objections to Marx. It is the abandonment of democracy that I find particularly disastrous". ${ }^{36}$ While intellectuals such as Shaw, the Webbs and many of a younger generation in the thirties admired the Soviet experiment, Russe!! remained "staunchly unimpressed by Lenin and Stalin". ${ }^{37}$ The elder statesman of the British Left, Fenner Brockway, says unreservedly that for the young men who were mesmerized by the Russian Revolution, Russell brought "me and many others to the value of personal liberty. He was decisive at a time of much mental stress". ${ }^{38}$

At a later period in his life Russell became an actor on the world stage, a practical philosopher campaigning for reason among statesmen. But he rose above partisan social and political analysis and argumentation to speak for mankind's further interests in the dangerous period of nuclear weaponry. These essays of impassioned resistance to a possible squandering of all civilization through use of nuclear weapons in the struggle of capitalism with communism raised the debate to a higher political level. In the magnificent essay, "Man's Peril", he asks, "What steps can be taken to prevent a military contest of which the issue must be disastrous to all sides?" He flatly states that

if the issues between East and West are to be decided in any manner that can give any possible satisfaction to anybody, whether communist or anti-communist, whether Asian or European or American, whether white or black, then these issues must not be decided by war. I should wish this to be understood on both sides of the Iron Curtain. ${ }^{39}$

"Man's Peril" is only one of Russell's classic English essays. More than 50 years before, he had written another masterpiece. "The Free Man's Worship" (1903) confronts the temptation to despair in a dehumanized universe described by science. This essay reminds us of Tennyson's answer to despair in "In Memoriam", or Arnold's in "Dover Beach", but Russell is adapting his faith to a more radical onslaught on human confidence than that which the Victorians had to face. His answer to despair is "to abandon the struggle for private happiness, to expel all eagerness of temporary desire, to burn with

${ }^{36}$ Portraits from Memory, p. 212.

${ }^{37}$ George Watson, Politics and Literature in Modem Britain (Totawa, N.J.: Rownan and Littlefield, 1977), p. 76.

${ }^{38}$ Fenner Brockway, Towards Tomorrow: The Autobiography of Fenner Brockway (London: Hart-Davis MacGibbon, 1977), p. 168.

${ }^{39}$ Portraits from Memory, p. 215. 
passion for eternal things - this is emancipation, and this is the free man's worship". ${ }^{40}$ Russell did not always live up to this lofty ideal; the twists and turns of his "private happiness" and the terrible insistence of "temporary desire" often made his life a torment. But they did not change the nobility of his aspirations. Russell campaigned for new freedoms in sexual relationships, freedoms which when realized brought new ambiguities and compromises. But he was fearless in stating what he believed and he was always accountable: ready for the consequences of his arguments and actions. Russell, for all the turmoil of his private life, remains a moralist of the first order whose thinking about all forms of freedom urgently needs study today.

It is not necessary to accept each cause Russell promoted to agree that his essays have given powerful impetus to the liberal view that every man must weigh the pros and cons of moral issues to decide them for himself. Russell was aware that encroaching social organization makes this difficult, as he discusses in his Reith lectures. ${ }^{41}$ Further, he knew that man needs to be appealed to against his own self-destructiveness. In "Can Men be Rational?" he writes, "I believe that the control of our acts by our intelligence is ultimately what is of most importance, and what alone will make social life remain possible as science increases the means at our disposal for injuring each other". ${ }^{42}$ As with most perils that have surfaced in our time, Russell was early in detecting them and persistent in seeking remedies.

Russell consistently defended the individual against mass opinion and manipulation by those who had superior power. He held that advances in civilization come from individual initiative and that these are often obscure and fragile. There are certainly other twentiethcentury essayists who eloquently defend individual rights and who speak for civilized man's future as well as his past. E.M. Forster, George Orwell, Aldous Huxley, Lewis Mumford and Jacob Bronowski, to name a few of the most important, have assisted us to see the new situation that science and technology have introduced. Russell the essayist needs to be studied in relation to these and other such writers. It may nevertheless be said that, more than they, Russell transmits into our time the nineteenth-century liberal values that are practical and workable, the foundation stones of every democracy new or old. Like Bacon in the Renaissance, Russell wrote

${ }^{40}$ Mysticism and Logic and Other Essays (London: Longmans, Green, 1918), p. 58.
${ }^{41}$ Authority and the Individual (London: George Allen \& Unwin, 1949).

${ }^{42}$ Sceptical Essays (London: George Allen \& Unwin, 1928), p. 53. to provide a value system for the emergent twentieth century. His thought could not be more central to the everyday intellectual concerns that activate our society. It is probable that when literary history catches up with him, Russell will be judged the master essayist of our time. 